\title{
ARTIKEL PENELITIAN \\ HUBUNGAN OBESITAS DENGAN KEJADIAN HIPERTENSI PADA MASYARAKAT ETNIK MINANGKABAU DI KOTA PADANG
}

\author{
Delmi Sulastri, Elmatris, Rahmi Ramadhani \\ Bagian Gizi Fakultas Kedokteran Universitas Andalas \\ email : delmisulastri@yahoo.com
}

\begin{abstract}
Abstrak
Hipertensi merupakan masalah kesehatan yang sering ditemukan di tengah masyarakat dan mengakibatkan angka kesakitan yang tinggi. Banyak faktor yang dapat memicu terjadinya hipertensi, salah satunya adalah obesitas.

Penelitian dengan tujuan untuk melihat hubungan antara kejadian obesitas dengan hipertensi ilakukan pada masyarakat etnik Minangkabau di 8 kelurahan di kota Padang. Penelitian ini merupakan studi komparatif menggunakan desain cross sectional study, dengan jumlah sampel 204 orang. Pengumpulan data karakteritik dilakukan melalui wawancara dan pengukuran tekanan darah, berat badan, tinggi badan, dan lingkar perut dilakukan dengan cara yang direkomendasikan WHO. Analisis statistik yang digunakan adalah uji chi square dan uji Independent sample T-test.

Hasil penelitian menemukan bahwa lebih dari separuh penderita hipertensi mengalami obesitas $(56,6 \%)$ dan obesitas sentral $(54,9 \%)$ terdapat hubungan bermakna antara obesitas dengan kejadian hipertensi $(\mathrm{p}<0,05 ; \mathrm{OR}=1,82)$ dan obesitas sentral dengan kejadian hipertensi $(\mathrm{p}<0,05 ; \mathrm{OR}=2,72)$. Uji Independent sample T-test menunjukkan hasil yang signifikan $(\mathrm{p}<0,05)$ dimana ada perbedaan rata-rata IMT $(\mathrm{p}=0,025)$ antara responden hipertensi dan tidak hipertensi dan ada perbedaan rata-rata LP $(p=0,002)$ antara responden hipertensi dan tidak hipertensi.

Hasil penelitian menyimpulkan bahwa terdapat hubngan antara kejadian obesitas dan obesitas sentral dengan hipertensi pada masyarakat etnik Minangkabau di kota Padang.
\end{abstract}

Kata kunci : Hipertensi, obesitas, obesitas sentral

\section{Abstract}

Hypertension is a common health problem in the community and lead to high morbidity. Many factors can lead to hypertension, one of which is obesity.

The Aim of this study was investigated the relationship of obesity with the incidence of hypertension, was conducted at the Minangkabau ethnic communities in 8 districts in the city of Padang. This research is a comparative study using a cross sectional study, with a sample of 204 people. Data collection was done with the interview respondent characteristics. Measurement of blood pressure, weight, 
height, waist and carried out by the WHO recommended. The statistical analysis used was chi square test and independent sample t-test.

Results of the study found that more than half of obese patients with hypertension $(56,6 \%)$ and central obesity $(54,9 \%)$. Chi-square statistical test showed there was a significant association between obesity and the incidence of hypertension ( $p$ $<0,05 ;$ OR $=1,82)$. Likewise with central obesity, showed a significant association with the incidence of hypertension $(\mathrm{p}<0,05$; $\mathrm{OR}=2,72)$. Independent sample t-test showed there was a significant mean difference BMI (Body Mass Index) between hypertension respondent and normotension respondent $(p=0,025)$ and there was a significant mean difference WC (waist circumference) between hypertension respondent and normotension respondent $(\mathrm{p}=0,002)$.

The conclution of the study suggest association between obesity with hypertension in Minangkabau ethnic communities in the Padang city.

Key word: Hypertension, Obesity, central obesity 


\section{PENDAHULUAN}

Hipertensi merupakan masalah kesehatan yang sering ditemukan di tengah masyarakat dan mengakibatkan angka kesakitan yang tinggi. ${ }^{(1)}$ Saat ini hipertensi telah menjadi masalah global karena prevalensinya yang terus meningkat dari tahun ke tahun. ${ }^{(2)}$ Penyakit ini dapat memicu penyakit lain seperti stroke, penyakit jantung koroner, gagal jantung, dan penyakit ginjal, ${ }^{(3)}$ sehingga penanganan harus segera dilakukan sebelum komplikasi dan akibat buruk lainnya terjadi. ${ }^{(4)}$ Komplikasi yang ditimbulkannya dapat menurunkan umur harapan hidup penderitanya. ${ }^{(5)}$

Menurut WHO tahun 2000 sekitar 972 juta jiwa penduduk di dunia menderita hipertensi dengan persentase pada pria sebesar $26,6 \%$ dan pada wanita $26,1 \%$. Insiden di negara maju 333 juta dan 639 juta di negara berkembang, termasuk Indonesia. ${ }^{(2)}$ Prevalensi hipertensi di Indonesia menurut hasil RISKESDAS 2007 adalah $31,7 \%$ dari total jumlah penduduk dewasa. Hipertensi menempati urutan ketiga penyebab kematian terbanyak setelah stroke dan tuberkulosis. Jumlahnya mencapai $6,8 \%$ dari proporsi penyebab kematian pada semua umur di Indonesia. ${ }^{(6)}$ Prevalensi hipertensi di Sumbar sendiri mencapai $31,2 \%$, dimana kota Padang tercatat menyumbang sebesar $26 \%{ }^{(7)}$ Berdasarkan laporan dari seluruh Puskesmas di kota Padang, pada tahun 2009 hipertensi menempati peringkat 5 penyakit yang banyak diderita penduduk kota Padang (26.456 kasus atau $8,1 \%$ ) dan menyebabkan kematian sebanyak 32 orang atau sekitar $8,72 \% .{ }^{(8)}$ Hal ini menunjukkan insiden hipertensi di kota Padang cukup tinggi dan harus diselesaikan segera.

Sembilan puluh lima persen penderita hipertensi tidak diketahui penyebabnya dan dikenal sebagai hipertensi primer atau esensial. Beberapa mekanisme yang mungkin berkontribusi untuk terjadinya hipertensi ini telah diidentifikasi, namun belum satupun teori yang tegas menyatakan patogenesis hipertensi tersebut. Obesitas merupakan salah satu faktor risiko yang erat kaitannya dengan penyakit ini.

Penelitian yang meneliti tentang hubungan obesitas dengan hipertensi telah banyak dilakukan. Penelitian yang dilakukan oleh Lilyasari dkk menunjukkan sebagian besar subyek dengan tekanan darah tinggi mengalami obesitas. $^{(9)}$ Estimasi risiko dari Framingham Heart Study menunjukkan bahwa 78\% hipertensi pada laki-laki dan $65 \%$ hipertensi pada wanita secara langsung berhubungan dengan obesitas. ${ }^{(10)}$ Data dari NHANES III memperlihatkan hubungan linier yang bermakna antara peningkatan BMI dengan tekanan darah dan tekanan nadi pada populasi Amerika. ${ }^{(11)}$ Pada populasi MONICA-Jakarta ditemukan bahwa persentase hipertensi pada individu yang overweight sebesar 24,5\% dan obesitas $27,5 \%$ jauh lebih tinggi dibandingkan individu dengan berat badan normal $12,5 \% .^{(12)}$

Obesitas dapat menimbulkan terjadinya hipertensi melalui berbagai mekanisme, baik secara langsung maupun tidak langsung. Secara langsung obesitas dapat menyebabkan peningkatan cardiac output karena makin besar massa tubuh makin banyak pula jumlah darah yang beredar sehingga curah jantung ikut mening-kat. (13) Sedangkan secara tidak langsung melalui perangsangan aktivitas sistem saraf simpatis dan Renin Angiotensin Aldosteron System (RAAS) oleh mediator-mediator seperti hormon, sitokin, adipokin, dsb. Salah satunya adalah hormon aldosteron yang terkait 
erat dengan retensi air dan natrium sehingga volume darah meningkat. ${ }^{(14)}$

Kejadian hipertensi yang disertai dengan obesitas ini dipengaruhi oleh usia, jenis kelamin, dan etnis. Usia 35 - 65 tahun merupakan usia yang dianggap paling banyak menderita hipertensi dengan obesitas ini. Hal ini terlihat dari survei yang dilakukan oleh Framingham Heart Study dimana dari 5209 partisipan, dua pertiganya berusia 35-65 tahun. ${ }^{(10)}$ Data dari RISKESDAS juga menunjukkan hal yang sama dimana prevalensi hipertensi dan obesitas lebih sering terjadi pada usia antara 35-65 tahun. ${ }^{(15)}$

Penelitian yang dilakukan oleh Framingham Heart Study menunjukkan risiko kejadian hipertensi meningkat 2,6 kali pada subyek laki-laki obesitas dan meningkat 2,2 kali pada subyek wanita obesitas dibandingkan subyek dengan berat badan normal. ${ }^{(10)}$ Sedangkan penelitian yang dilakukan oleh Liputo dkk menunjukkan sebaran penderita Sindrom Metabolik (Hipertensi dan Obesitas) berdasarkan jenis kelamin, lebih banyak dialami oleh perempuan $(26,8 \%)$ dan hanya $6,3 \%$ pada responden laki-laki. ${ }^{(16)}$

Etnis diduga berpengaruh terhadap kejadian hipertensi yang disertai dengan obesitas. Berdasarkan the ARIC study yang meneliti dua etnik populasi di Amerika menyatakan bahwa prevalensi hipertensi lebih tinggi pada penduduk Amerika Afrika dibanding kulit putih $(55 \%$ laki-laki Amerika Afrika vs 29\% laki-laki kulit putih; 56\% wanita Amerika Afrika vs $26 \%$ wanita kulit putih). Pria dan wanita dengan hipertensi memiliki rata-rata Indeks Masa Tubuh (IMT) dan Lingkaran Perut (LP) lebih tinggi dibanding yang tidak hipertensi. Wanita etnik Amerika Afrika memiliki BMI dan WC lebih tinggi dibanding wanita kulit putih, tapi berbeda dengan prianya yang memiliki
BMI yang sama dan WC yang lebih rendah dibanding pria kulit putih. ${ }^{(17)}$

Sumbar yang sebagian besar masyarakatnya beretnis Minangkabau juga berisiko untuk terkena hipertensi dan obesitas ini. Hal ini terlihat dari penelitian yang dilakukan oleh Lipoeto dkk pada etnis Minangkabau di kabupaten Padang Pariaman. Hasil penelitiannya menunjukkan bahwa persentase lingkar pinggang laki-laki yang termasuk kategori lingkar pinggang besar adalah 12,5\%, sedangkan pada perempuan sebanyak $48,7 \%$. Selain itu ditemukan sebanyak 21 orang responden menderita Sindrom Metabolik (hipertensi, obesitas, hiperglikemia, dislipidemia) dan terdapat korelasi yang positif antara lingkar pinggang sebagai indikator obesitas sentral dengan tekanan darah. ${ }^{(16)}$

Etnis Minangkabau mempunyai kekhasan tersendiri dalam tradisi dan budayanya. Makanan tradisional Minangkabau seperti rendang diklaim mengandung lemak jenuh tinggi. Minyak kelapa dan santan yang digunakan sebagai bahan utama membuat rendang merupakan sumber utama kaya asam lemak jenuh atau SAFA (saturated fatty acid). Etnik Jawa juga mempunyai makanan tradisional kaya santan seperti gudeg, tapi santan yang dipakai tidak sekental santan untuk rendang, sehingga kandungan SAFA tidak terlalu tinggi. ${ }^{(16)}$ Selain itu berdasarkan data RISKESDAS 2007 masyarakat Minangkabau hanya 5\% yang cukup mengonsumsi sayur dan buah, sedangkan hampir seluruh penduduk (95\%) kurang mengonsumsi sayur dan buah, padahal sayur dan buah merupakan sumber serat yang dapat menghambat absorpsi lemak. ${ }^{(15)}$ Hasil penelitian Sulastri dkk pada etnik Minangkabau menunjukkan sebagian besar responden mengalami hiperkolesterolemia, konsumsi bahan 
makanan yang merupakan sumber zat ini dilakukan atas pertimbangan yang dapat menurunkan kadar lemak perbedaan pola makan di antara kedua darah yakni sayur dan buah tidak lokasi tersebut. Dari ke 4 kecamatan dilakukan setiap kali makan, sedangkan dilakukan pemilihan daerah tempat pada setiap kali makan terdapat bahan pengambilan sampel dengan cara multi sumber lemak jenuh yaitu santan (gulai, stage random sampling sedangkan rendang) dan atau minyak kelapa sawit. sampel diperoleh dengan memBerdasarkan survei pendahuluan di perhatikan kriteria eksklusi (Hipertensi kelurahan Jati kecamatan Padang Timur sekunder, perokok berat, menjalani kota Padang dari sepuluh orang etnik diet ) pada tiap - tiap lokasi yang Minangkabau yang diperiksa tekanan sudah ditentukan dilakukan dengan darahnya ada delapan orang yang metoda sistematik random sampling. menderita hipertensi, dan dari delapan orang tersebut ada tujuh orang yang mengalami obesitas. Berdasarkan hal di atas maka peneliti tertarik untuk mengetahui lebih lanjut apakah terdapat hubungan antara obesitas dengan kejadian hipertensi pada masyarakat etnik Minangkabau di kota Padang.

\section{METODE PENELITIAN}

Desain dan lokasi Penelitian : Penelitian ini adalah studi komperatif dengan desain cross sectional study, dilakukan di 4 kecamatan di kota Padang provinsi Sumatera Barat.

Populasi dan sampel : Populasi adalah semua penderita hipertensi dan normotensi yang berusia antara $35-65$ tahun, etnik Minang (berdomisili di Sumatera Barat, kedua orang tua dan kakek nenek berasal dari Sumatera Barat) dan diperoleh melalui penjaringan terhadap 800 orang sampel yang tersebar di 4 kecamatan di Kota Padang Prov. Sumatera Barat. Sampel diambil dengan menggunakan rumus untuk $n 1=n 2=(z \dot{\alpha} \sqrt{2} P Q+z \beta \sqrt{ } P 1 Q 1+$ $P 2 Q 2)^{2} /(P 1-P 2)$, didapatkan jumlah $\mathrm{n} 1=\mathrm{n} 2=102$ orang.

Sampel diambil dengan cara porposif untuk menentukan kecamatan yang mewakili dengan 2 daerah berlokasi di sepanjang pantai dan 2 daerah lainnya berada jauh dari pantai. . Hal

\section{Pengumpulan data}

Data karakteristik diperoleh melalui wawancara menggunakan kuesioner serta pengukuran tekanan darah, Berat Badan, Tinggi Badan dan lingkaran perut

\section{Analisis data}

Analisis univariat, untuk melihat distribusi data masing - masing variabel dan kemudian disajikan dalam bentuk tabel dan diagram . Data terdiri dari karakteristik,IMT dan lingkaran perut.

Analisis bivariat, untuk melihat hubungan antara variabel dependen dengan variabel independen dengan menggunakan t-test dan chi-square dengan derajat kepercayaan 95\%.

\section{HASIL PENELITIAN}

\section{Gambaran Umum Lokasi Penelitian}

Kecamatan Padang Selatan merupakan salah satu kecamatan di Kota Padang yang berbatasan langsung dengan Samudera Hindia di sebelah barat. Kecamatan Padang Selatan memiliki luas daerah $10,03 \mathrm{~km}^{2}$ yang terbagi ke dalam 12 kelurahan. Dalam penelitian ini, ada 2 kelurahan yang dijadikan lokasi dalam penelitian ini, yaitu kelurahan Mata Air dan kelurahan Rawang. Kelurahan Mata Air memiliki luas wilayah $0,8 \mathrm{~km}^{2}$ dengan populasi 11.346 jiwa, terdiri atas $13 \mathrm{RW} 46 \mathrm{RT}$. 
Kelurahan Rawang memiliki luas Kecamatan Koto Tangah merupakan wilayah $0,5 \mathrm{~km}^{2}$ dengan popoulasi Kecamatan yang terbesar di kota 11.310, terdiri atas $13 \mathrm{RW}$ dan 46 RT. Padang yang berpenduduk 161.799

Kecamatan Padang Timur jiwa, 41.007 KK, 664 RT, 173 RW memiliki luas wilayah $8,15 \mathrm{~km}^{2}$ yang dengan luas wilayah $232,25 \mathrm{~km}^{2}$ yang terdiri dari 10 kelurahan. Kelurahan terdiri dari 13 kelurahan. Kelurahan yang dijadikan sebagai lokasi dalam yang dijadikan sebagai lokasi dalam penelitian ini adalah kelurahan Jati dan penelitian ini adalah kelurahan Parupuk kelurahan Ganting Parak Gadang. Tabing dan kelurahan Koto Pulai. Kelurahan Jati memiliki luas wilayah Kelurahan Parupuk Tabing memiliki $0,61 \mathrm{~km}^{2}$ dengan populasi penduduk luas wilayah $9,41 \mathrm{~km}^{2}$ dengan jumlah 11.722 jiwa, terdiri dari 9 RW dan 33 penduduk 12.028 jiwa. Kelurahan ini RT. Kelurahan Ganting Parak Gadang terdiri dari berbagai macam etnis, memiliki luas wilayah $0,8 \mathrm{~km}^{2}$ dengan disamping etnis Minang, ada Jawa, jumlah penduduk 11.755 jiwa terdiri Nias, dan Cina. Kelurahan ini dari $11 \mathrm{RW}$ dan $47 \mathrm{RT}$. mempunyai 18 RW dan 80 RT. Kecamatan Kuranji memiliki Kelurahan Koto Pulai memiliki luas luas wilayah $57,41 \mathrm{~km}^{2}$ yang terdiri atas 9 kelurahan. Kelurahan yang dijadikan sebagai lokasi dalam penelitian ini adalah kelurahan Korong Gadang dan kelurahan Ampang. Kelurahan Korong Gadang memiliki luas wilayah $7,05 \mathrm{~km}^{2}$ dengan populasi penduduk 17.111 jiwa, terdiri atas $16 \mathrm{RW}$ dan 59 RT. Kelurahan Ampang memiliki luas wilayah $4,03 \mathrm{~km}^{2}$ dengan populasi penduduk 6.052, terdiri atas $8 \mathrm{RW}$ dan $23 \mathrm{RT}$.

wilayah $5,53 \mathrm{~km}^{2}$ dengan populasi penduduk 9.282 jiwa, terdiri atas $3 \mathrm{RW}$ dan 10 RT.

\section{Karakteristik Responden}

Responden dalam penelitian ini adalah masyarakat Etnik Minangkabau usia 35-65 tahun di 8 kelurahan di kota Padang. Berdasarkan penelitian yang telah dilaksanakan, diperoleh informasi mengenai gambaran karakteristik responden sebagai berikut:

Tabel 1. Distribusi Responden Hipertensi Berdasarkan Umur, Jenis Kelamin, Status Perkawinan, dan Tingkat Pendidikan

\begin{tabular}{|c|c|c|c|c|c|}
\hline \multirow{2}{*}{\multicolumn{2}{|c|}{ Karakteristik }} & \multicolumn{2}{|c|}{ Hipertensi } & \multicolumn{2}{|c|}{ Tidak Hipertensi } \\
\hline & & f & $\%$ & f & $\%$ \\
\hline \multicolumn{6}{|l|}{ Umur } \\
\hline- & $35-45$ th & 24 & 23,5 & 23 & 22,5 \\
\hline - & $46-55$ th & 32 & 31,4 & 33 & 32,4 \\
\hline- & $56-65$ th & 46 & 45,1 & 46 & 45,1 \\
\hline Jumlah & & 102 & 100 & 102 & 100 \\
\hline \multicolumn{6}{|c|}{ Jenis Kelamin } \\
\hline - & Laki-laki & 23 & 22,5 & 23 & 22,5 \\
\hline - & Perempuan & 79 & 77,5 & 79 & 77,5 \\
\hline Jumlah & & 102 & 100 & 102 & 100 \\
\hline \multicolumn{6}{|c|}{ Status Perkawinan } \\
\hline- & Belum kawin & 0 & 0 & 2 & 2 \\
\hline- & Kawin & 88 & 86,3 & 88 & 86,3 \\
\hline- & Janda/duda & 14 & 13,7 & 12 & 11,8 \\
\hline Jumlah & & 102 & 100 & 102 & 100 \\
\hline
\end{tabular}


DENGAN KEJADIAN HIPERTENSI PADA MASYARAKAT ETNIK MINANGKABAU DI KOTA PADANG

\begin{tabular}{|c|c|c|c|c|}
\hline \multicolumn{5}{|l|}{ Tingkat Pendidikan } \\
\hline $\begin{array}{l}\text { - } \quad \text { Tidak } \\
\text { sekolah/tidak tamat SD }\end{array}$ & 13 & 12,7 & 3 & 2,9 \\
\hline Tamat SD & 31 & 30,4 & 20 & 19,6 \\
\hline Tamat SMP & 16 & 15,7 & 23 & 22,5 \\
\hline Tamat SMA & 27 & 26,5 & 35 & 34,3 \\
\hline Tamat akademi/PT & 15 & 14,7 & 21 & 20,6 \\
\hline Jumlah & 102 & 100 & 102 & 100 \\
\hline
\end{tabular}

Berdasarkan Tabel 1 dapat dilihat berstatus kawin sebanyak 88 orang bahwa pada kelompok hipertensi, $(86,3 \%)$ dan tingkat pendidikan tamat paling banyak adalah responden yang SD sebanyak 31 orang $(30,4 \%)$.

berumur 56-65 tahun yaitu sebanyak 46 orang (45,1\%). Berdasarkan jenis kelamin, responden wanita lebih banyak Analisis univariat bertujuan untuk dibanding laki-laki yakni sebanyak 79 melihat distribusi frekuensi masingorang $(77,5 \%)$. Dilihat dari status masing variabel baik variabel dependen perkawinan dan tingkat pendidikan, maupun variabel independen. paling banyak adalah responden yang

Tabel 2. Rata-Rata Tekanan Darah Responden Penelitian

\begin{tabular}{lccccc}
\hline Kelompok & f & Mean & SD & Min & Maks \\
\hline Hipertensi & 102 & & & & \\
TDS & & 157,96 & 17,65 & 120 & 217,50 \\
TDD & & 92,20 & 7,67 & 70 & 117,50 \\
Tidak Hipertensi & 102 & & & & \\
TDS & & 118,25 & 9,42 & 100 & 139 \\
TDD & & 76 & 6,12 & 60 & 88 \\
\hline
\end{tabular}

Berdasarkan Tabel 2. dapat dilihat dan rata-rata tekanan darah diastolik bahwa rata-rata tekanan darah sistolik adalah $76 \pm 6,12 \mathrm{mmHg}$ dengan tekanan (TDS) pada kelompok hipertensi adalah darah sistolik terendah $100 \mathrm{mmHg}$ dan $157,96 \pm 17,65 \mathrm{mmHg}$ dan rata-rata tertinggi adalah $139 \mathrm{mmHg}$, sedangkan tekanan darah diastolik (TDD) adalah tekanan darah diastolik terendah adalah $92,20 \pm 7,67 \mathrm{mmHg}$ dengan tekanan $60 \mathrm{mmHg}$ dan tertinggi adalah 88 darah sistolik terendah $120 \mathrm{mmHg}$ dan $\mathrm{mmHg}$. tertinggi $217,50 \mathrm{mmHg}$, sedangkan tekanan darah diastolik terendah adalah Indeks Massa Tubuh (IMT) $70 \mathrm{mmHg}$ dan tertinggi $117,50 \mathrm{mmHg}$. Indeks Massa Tubuh (IMT) responden Pada kelompok tidak hipertensi, hasil didapatkan dengan membagi berat pengukuran tekanan darah badan $(\mathrm{kg})$ responden dengan kuadrat menunjukkan rata-rata tekanan darah tinggi badan $\left(\mathrm{m}^{2}\right)$. sistolik adalah $118,25 \pm 9,42 \mathrm{mmHg}$

Tabel 3. Rata-Rata IMT Responden Penelitian

\begin{tabular}{|l|c|c|c|c|c|}
\hline Kelompok & Mean & SD & Min & Maks & p value \\
\hline Hipertensi & 26,58 & 4,36 & 18,39 & 42,86 & 0,025 \\
\hline
\end{tabular}




\begin{tabular}{|l|l|l|l|l|l|}
\hline Tidak Hipertensi & 25,21 & 4,29 & 15,96 & 40,37 & \\
\hline
\end{tabular}

Berdasarkan Tabel 3. dapat dilihat $\pm 4,29 \mathrm{~kg} / \mathrm{m}^{2}$ dengan nilai IMT terendah bahwa hasil pengukuran rata-rata IMT $15,96 \mathrm{~kg} / \mathrm{m}^{2}$ dan tertinggi $40,37 \mathrm{~kg} / \mathrm{m}^{2}$. responden hipertensi adalah 26,58 \pm Uji analisis T-test didapatkan perbedaan $4,36 \mathrm{~kg} / \mathrm{m}^{2}$ dengan nilai IMT terendah bermakna rata-rata IMT antara $18,39 \mathrm{~kg} / \mathrm{m}^{2}$ dan tertinggi $42,86 \mathrm{~kg} / \mathrm{m}^{2}$. responden hipertensi dan tidak Pada responden tidak hipertensi hasil hipertensi $(\mathrm{p}<0.05)$. pengukuran rata-rata IMT adalah 25,21

Gambar 1. Distribusi Frekuensi Obesitas pada Responden Hipertensi dan Tidak Hipertensi

Berdasarkan Gambar 1. diatas dapat Lingkar Perut (LP) dilihat bahwa proporsi kejadian Lingkar Perut (LP) responden hipertensi lebih banyak terjadi pada didapatkan dengan melakukan responden yang obesitas yakni sebesar pengukuran memakai pita pengukur. $56,6 \%$.

Tabel 4. Rata-Rata Lingkar Perut Responden Penelitian

\begin{tabular}{|l|c|c|c|c|c|}
\hline Kelompok & Mean & SD & Min & Maks & p value \\
\hline Hipertensi & 92,57 & 9,38 & 60 & 121 & \multirow{2}{*}{0,002} \\
\hline Tidak Hipertensi & 87,36 & 14,07 & 25,8 & 120 & \\
\hline
\end{tabular}

Berdasarkan Tabel 4 dapat dilihat lingkar perut adalah $87,36 \pm 14,07 \mathrm{~cm}$ bahwa hasil pengukuran rata-rata dengan nilai lingkar perut terendah 25,8 lingkar perut responden hipertensi $\mathrm{cm}$ dan lingkar perut tertinggi $120 \mathrm{~cm}$. adalah 92,57 \pm 9,38 $\mathrm{cm}$ dengan lingkar Uji analisis T-test didapatkan perbedaan perut terendah $60 \mathrm{~cm}$ dan lingkar perut bermakna lingkaran perut antara tertinggi $121 \mathrm{~cm}$. Pada responden tidak responden hipertensi dan normotensi hipertensi hasil pengukuran rata-rata $(\mathrm{p}<0.05)$. 
Gambar 2. Distribusi Frekuensi Obesitas Sentral pada Responden Hipertensi dan Tidak Hipertensi

Berdasarkan Gambar 2 diatas dapat responden yang mengalami obesitas dilihat bahwa proporsi kejadian sentral yakni sebesar 54,9\%.

hipertensi lebih banyak terjadi pada

Tabel 5. Hubungan Obesitas dengan Kejadian Hipertensi

\begin{tabular}{|c|c|c|c|c|c|c|c|c|}
\hline \multirow{3}{*}{ Obesitas } & \multicolumn{4}{|c|}{ Hipertensi } & \multirow{2}{*}{\multicolumn{2}{|c|}{ Total }} & \multirow{3}{*}{ p value } & \multirow{3}{*}{$\begin{array}{c}\text { OR } \\
(95 \% \text { CI })\end{array}$} \\
\hline & \multicolumn{2}{|c|}{ Ya } & \multicolumn{2}{|c|}{ Tidak } & & & & \\
\hline & $f$ & $\%$ & $f$ & $\%$ & $\mathrm{f}$ & $\%$ & & \\
\hline $\mathrm{Ya}$ & 64 & 56,6 & 49 & 43,4 & 113 & 100 & 0,049 & 1,82 \\
\hline Tidak & 38 & 41,8 & 53 & 58,2 & 91 & 100 & & $(1,042-3,185)$ \\
\hline Total & 102 & & 102 & & 204 & & & \\
\hline
\end{tabular}

Berdasarkan Tabel 5 dapat dilihat dengan hipertensi $(p<0,05)$. dengan proporsi responden yang mengalami Nilai OR $=1,82$ dan 95\% CI $(1,042-$ hipertensi lebih banyak terjadi pada 3,185), artinya obesitas merupakan responden obesitas bila dibandingkan faktor risiko terjadinya hipertensi, dengan responden yang tidak obesitas. dimana responden yang mengalami Hasil uji statistik dengan menggunakan obesitas berisiko untuk hipertensi 1,82 chi square, diperoleh hububgan kali jika dibandingkan dengan bermakna antara kejadian obesitas responden yang tidak obesitas.

Tabel 6. Hubungan Obesitas Sentral dengan Kejadian Hipertensi

\begin{tabular}{|c|c|c|c|c|c|c|c|c|}
\hline \multirow{3}{*}{$\begin{array}{c}\text { Obesitas } \\
\text { Sentral }\end{array}$} & \multicolumn{4}{|c|}{ Hipertensi } & \multirow{2}{*}{\multicolumn{2}{|c|}{ Total }} & \multirow{3}{*}{ p value } & \multirow{3}{*}{$\begin{array}{c}\text { OR } \\
(95 \% \mathrm{CI}) \\
\end{array}$} \\
\hline & \multicolumn{2}{|c|}{ Ya } & \multicolumn{2}{|c|}{ Tidak } & & & & \\
\hline & $\mathbf{f}$ & $\%$ & $\mathbf{f}$ & $\%$ & $\mathbf{f}$ & $\%$ & & \\
\hline $\mathrm{Ya}$ & 89 & 54,9 & 73 & 45,1 & 162 & 100 & 0,009 & 2,72 \\
\hline Tidak & 13 & 31 & 29 & 69 & 42 & 100 & & $(1,319-5,608)$ \\
\hline
\end{tabular}




\begin{tabular}{llll}
\hline Total & 102 & 102 & 204 \\
\hline
\end{tabular}

Berdasarkan Tabel 6. dapat dilihat penelitian ini menunjukkan bahwa proporsi responden yang mengalami kenaikan nilai IMT diikuti dengan hipertensi lebih banyak terjadi pada kenaikan tekanan darah. Artinya responden obesitas sentral bila semakin tinggi IMT seseorang semakin dibandingkan dengan responden yang besar pula peluangnya untuk terkena tidak obesitas sentral. Hasil uji statistik hipertensi. ${ }^{(18)}$

dengan menggunakan chi square, Berdasarkan distribusi frekuensi terdapat hubungan yang bermakna obesitas pada responden hipertensi dan antara kejadian obesitas sentral dengan tidak hipertensi didapatkan proporsi hipertensi. Nilai OR $=2,72$ dan $95 \%$ CI kejadian hipertensi lebih banyak terjadi $(1,319-5,608)$, artinya obesitas sentral pada responden yang obesitas yakni merupakan faktor risiko terjadinya sebesar 56,6\%. Hal ini sesuai dengan hipertensi, dimana responden yang survei yang dilakukan pada populasi mengalami obesitas sentral berisiko MONICA (Monitoring Trends and untuk hipertensi 2,72 kali jika Determinant in Cardiovascular) di dibandingkan dengan responden yang Jakarta yang menyebutkan bahwa tidak obesitas sentral.

\section{PEMBAHASAN}

\section{Hubungan Obesitas dengan Kejadian Hipertensi}

Berdasarkan hasil penelitian persentase hipertensi pada individu obesitas $27,5 \%$ jauh lebih tinggi dibandingkan individu dengan berat badan normal $12,5 \%{ }^{(12)} \quad$ Studi Framingham menunjukkan hal yang didapatkan rata-rata Indeks Massa Tubuh (IMT) responden hipertensi $26,58 \pm 4,36 \mathrm{~kg} / \mathrm{m}^{2}$ dengan nilai IMT terendah $18,39 \mathrm{~kg} / \mathrm{m}^{2}$ dan tertinggi $42,86 \mathrm{~kg} / \mathrm{m}^{2}$. Pada responden tidak hipertensi hasil pengukuran rata-rata IMT adalah $25,21 \pm 4,29 \mathrm{~kg} / \mathrm{m}^{2}$ dengan nilai IMT terendah $15,96 \mathrm{~kg} / \mathrm{m}^{2}$ dan tertinggi $40,37 \mathrm{~kg} / \mathrm{m}^{2}$. Hal ini menunjukkan rata-rata IMT pada responden hipertensi lebih tinggi dibandingkan dengan responden tidak hipertensi. Hal ini sejalan dengan penelitian yang dilakukan oleh Margaret M.Harris dkk, dimana Harris mendapatkan pada wanita kulit putih dengan hipertensi memiliki rerata IMT $29,1 \pm 6,1$, sedangkan pada yang tidak hipertensi memiliki rerata IMT 25,9 $\pm 4,9$ (Harris dkk, 2000). Penelitian yang dilakukan oleh Hendrik di Fakultas Kedokteran Universitas Sumatera Utara tahun 2012 juga menunjukkan hal yang sama. Hasil

serupa dimana dari 165 responden yang mengalami hipertensi, sebanyak 133 responden mengalami obesitas. Hal ini berarti hanya 32 orang saja yang tidak mengalami obesitas. ${ }^{(10)}$. Hasil penelitian Akintunde dkk juga menunjukkan hal yang sama, dimana dari 816 responden yang mengalami hipertensi esensial, lebih dari setengahnya (494 orang) mengalami obesitas. ${ }^{(19)}$

Hasil analisis independent sample T-test menunjukkan ada hubungan rerata IMT dengan hipertensi ( $p$ value $<0,05)$. Hasil uji statistik chi square menunjukkan ada hubungan yang bermakna antara obesitas dengan kejadian hipertensi $(p$ value $<0,05$ ) dengan nilai $\mathrm{OR}=1,82$. Hasil penelitian ini menunjukkan obesitas terbukti merupakan faktor resiko terjadinya hipertensi, dimana responden yang mengalami obesitas berisiko untuk hipertensi 1,82 kali jika dibandingkan dengan responden yang tidak obesitas. Hasil penelitian ini sejalan dengan 
penelitian yang dilakukan oleh $\mathrm{cm}$ (Harris dkk, 2000). Hasil penelitian

Manampiring AE dkk (2009) pada ini juga sejalan dengan penelitian yang penduduk di kelurahan Pakowa dilakukan oleh Arresta tahun 2008 yang kecamatan Wanea kota Manado yang menyatakan bahwa nilai LP berbanding sebagian besar beretnis Minahasa, lurus dengan peningkatan tekanan dimana hasilnya menunjukkan ada darah. Semakin besar lingkar perut hubungan yang bermakna antara status seseorang maka semakin besar pula gizi lebih dengan kejadian hipertensi. risikonya untuk terkena hipertensi. ${ }^{(22)}$

Penelitian ini juga sejalan dengan Berdasarkan perbandingan penelitian yang dilakukan oleh, dimana distribusi frekuensi obesitas sentral hasil penelitiannya menunjukkan ada pada responden hipertensi dan tidak hubungan obesitas dengan hipertensi hipertensi didapatkan proporsi kejadian pada karyawan tetap Universitas hipertensi lebih banyak terjadi pada Pembangunan Nasional Veteran Jakarta responden yang mengalami obesitas yang sebagian besar beretnis Jawa. ${ }^{(20)}$

Obesitas merupakan salah satu dari faktor resiko hipertensi. Seseorang yang memiliki berat badan berlebih atau mengalami obesitas akan membutuhkan lebih banyak darah untuk menyuplai oksigen dan makanan ke jaringan tubuhnya, sehingga volume darah yang beredar melalui pembuluh darah meningkat, curah jantung ikut meningkat dan akhirnya tekanan darah ikut meningkat. ${ }^{(13)}$ Selain itu kelebihan berat badan juga meningkatkan kadar insulin dalam darah. Peningkatan insulin ini menyebabkan retensi natrium pada ginjal sehingga tekanan darah ikut naik. ${ }^{(21)}$

\section{Hubungan Obesitas Sentral dengan Kejadian Hipertensi}

Berdasarkan hasil penelitian didapatkan rata-rata Lingkar Perut (LP) responden hipertensi adalah 92,57 \pm 9,38 cm, sedangkan pada responden tidak hipertensi rata-rata lingkar perut adalah 87,36 $\pm 14,07 \mathrm{~cm}$. Hal ini menunjukkan rata-rata lingkar perut responden hipertensi lebih tinggi jika dibandingkan dengan responden yang tidak hipertensi. Hal ini sesuai dengan penelitian Harris dkk yang menyatakan bahwa rata-rata LP wanita hipertensi adalah $100,4 \pm 15,8 \mathrm{~cm}$, sedangkan sentral yakni sebesar 54,9\%. Hasil yang sama juga dilaporkan oleh Arresta (2008) di Surabaya yang menemukan bahwa dari semua penderita yang terdiagnosis hipertensi, sebanyak $81 \%$ mengalami obesitas sentral. ${ }^{(22)}$ Sedangkan penelitian yang dilakukan oleh Abdus Sukkur di poli jantung Sidoarjo juga memperlihatkan bahwa dari 24 pasien yang mengalami obesitas sentral, sebagian besar mengalami hipertensi.

Hasil uji analisis dengan independent sample T-test menunjukkan ada hubungan yang bermakna antara beda rerata LP dengan hipertensi ( $p$ value $<0,05$ ). Hasil uji statistik chi square menunjukkan ada hubungan yang bermakna antara obesitas sentral dengan kejadian hipertensi ( $p$ value $<0,05$ ) dengan nilai $\mathrm{OR}=2,72$, artinya responden yang mengalami obesitas sentral berisiko 2,72 kali terkena hipertensi dibanding responden yang tidak obesitas sentral. Hal ini sejalan dengan penelitian yang dilakukan oleh Arresta (2008), yang menyatakan obesitas sentral berhubungan dengan hipertensi dimana nilai $\mathrm{p}=0,047$ dan nilai $\mathrm{OR}=5,21$. Selain itu, hasil penelitian yang dilakukan oleh Abdus Sukkur di poli jantung RSUD Sidoarjo tahun 2009 juga menyatakan hal yang serupa. Hasil penelitiannya menunjukpada wanita tidak hipertensi 90,9 $\pm 13,6$ kan bahwa ada hubungan lingkar 
pinggang dengan kejadian hipertensi dengan nilai $\mathrm{p}=0,032 .{ }^{(23)}$

Obesitas sentral dapat memicu terjadinya hipertensi. Hal ini terjadi karena pada obesitas sentral penumpukan lemak lebih banyak pada daerah abdomen. Jika lemak abdomen ini berlebihan akan menyebabkan beberapa hal diantaranya: menurunkan kadar adiponektin, menurunkan ambilan asam lemak bebas intrasel oleh mitokondria sehingga oksidasi berkurang, dan menyebabkan akumulasi asam lemak bebas intrasel. Kelebihan asam lemak bebas ini dapat memicu terjadinya resistensi insulin. Keadaan hiperinsulinemia ini dapat menyebabkan vasokonstriksi dan reabsorpsi natrium di ginjal, yang pada akhirnya mengakibatkan hipertensi. ${ }^{(24)}$

Seseorang dengan lingkar perut yang besar sangat berisiko untuk menderita hipertensi. Hal ini karena lingkar perut merupakan indikator banyaknya penumpukan lemak di daerah abdomen. Semakin besar nilai lingkar perut seseorang, maka semakin banyak pula penumpukan lemak di daerah abdomen. Penumpukan lemak di abdomen inilah yang disebut sebagai obesitas sentral. Penumpukan lemak di abdomen erat kaitannya dengan penumpukan kolesterol. Sel lemak pada perut mudah lepas dan bisa masuk ke pembuluh darah sehingga bisa menyebabkan tersumbatnya aliran darah. Pada akhirnya hal ini akan menyebabkan terjadinya hipertensi. ${ }^{(23)}$

\section{Kesimpulan}

Setelah dilakukan penelitian tentang hubungan obesitas dengan kejadian hipertensi pada masyarakat Etnik Minangkabau di kota Padang, maka dapat diambil kesimpulan sebagai berikut :

1. Terdapat perbedaan bermakna rata-rata IMT responden hipertensi dibandingkan dengan responden tidak hipertensi, dan lebih dari separuh penderita hipertensi mengalami obesitas.

2. Terdapat perbedaan yang bermakna rata-rata lingkaran perut responden hipertensi dibandingkan dengan responden yang tidak hipertensi, dan lebih dari separuh penderita hipertensi mengalami obesitas sentral

3. Terdapat hubungan yang bermakna antara obesitas dan obesitas sentral dengan kejadian hipertensi.

\section{KEPUSTAKAAN}

1. Bustan M.N. 2000. Epidemiologi penyakit tidak menular. Rineka Cipta: Jakarta, pp 61-9.

2. World Health Report. 2002. Reducing risks, promoting healthy life. World Health Organization: Geneva, Switzerland, D.

3. Sutanto. 2010. Cegah dan tangkal penyakit modern hipertensi, stroke, jantung, kolesterol, dan diabetes. Andi Offset: Yogyakarta, pp 1-33.

4. Lumbantobing S.M. 2008. Tekanan darah tinggi. Balai Penerbit Fakultas Kedokteran Universitas Indonesia: Jakarta, pp 1-24.

5. Bangun A.P. 2003. Terapi jus dan ramuan tradisional untuk hipertensi. Agromedia Pustaka : Jakarta, pp 15-21.

6. Kementerian Kesehatan. 2008. Laporan Nasional Riset Kesehatan Dasar (RISKESDAS) 2007. Badan Litbangkes, 
Depkes RI : Jakarta. Diakses di www.depkes.go.id .

7. Kementerian Kesehatan. 2009. Profil kesehatan Indonesia 2008. Badan Litbangkes, Depkes RI : Jakarta. Diakses di www.depkes.go.id

8. Dinas Kesehatan Kota Padang, 2010. Laporan tahunan tahun 2009 edisi 2010. DKK: Padang.

9. Lilyasari O. 2007. Hipertensi dengan obesitas adakah peran endotelin. J Kardiol Ind, 28(6): 460-75.

10. Wilson P.W.F, D.Agustino R.B., Sullivan L, Parise H, Kannel W.B. 2002. Overweight and obesity as determinants of cardiovascular risk. The Framingham Experience. Arc. Intern. Med. 2, 162:1867-2.

11. National Institutes of Health, National Heart, Lung, and Blood Intitute. 2003. The seventh report of the joint national committe on prevention, detection, evaluation and treatment of high blood pressure (JNC VII). Available at: http://www.nhlbi.nih.gov/guideli nes/hypertension/jn7full.pdf.

12. Arief I. 2007. Profil hipertensi pada populasi MONICA tahun 2000 (survey III). Diakses di http://www.pjnhk.go.id

13. Sheps SG. 2005. Mayo clinic hipertensi, mengatasi tekanan darah tinggi. Intisari Mediatama: Jakarta.
14. Nagase $M$ and Toshiro Fujita. 2009. Mineralocorticoid receptor activation in obesity hypertension. The Japanese Society of Hypertension. 32: 649-57.

15. Kementerian Kesehatan. 2008. Laporan Nasional Riset Kesehatan Dasar (RISKESDAS) 2007. Badan Litbangkes, Depkes RI : Jakarta. Diakses di www.depkes.go.id.

16. Lipoeto NI, Fasli Jalal, Fadhil Oenzil dan Novia Susanti. 2008. Lingkar pinggang, kadar glukosa darah, trigliserida dan tekanan darah pada etnis minang di kabupaten Padang Pariaman, Sumatera Barat. M Med Indonesiana, 43(3): 129-36.

17. Harris MM, June Stevens, Neal Thomas, Pam Schreiner, and Aaron R. Folsom. 2002. Association of fat distribution and obesity with hypertension in a bi-ethnic population: the ARIC Study. Obesity Research 8(7): 516-24.

18. Hendrik. 2012. Hubungan Indeks Massa Tubuh Dengan Tekanan Darah Pada Mahasiswa Fakultas Kedokteran Universitas Sumatera Utara. Skripsi Fakultas Kedokteran Universitas Sumatera Utara. Diakses di http://repository.usu.ac.id/handle /123456789/31021.

19. Akintunde AA, Akinwusi PO, Adebayo RA, Ogunyemi S, Opadijo OG. 2010. Burden of obesity in essential hypertension: pattern and 
prevalence. Niger J Clin Pract, 13(4): 399-402.

20. Rachmawaty. 2011. Hubungan antara usia, obesitas, dan prilaku merokok dengan hipertensi pada karyawan UPN Veteran Jakarta yang berjenis kelamin laki-laki. Skripsi Fakultas Kedokteran UPN Veteran Jakarta. Diakses di www.library.upnvj.ac.id .

21. Morrison R. 2006. The zucker rat as a model of obesityhypertension. Thesis, University of Marshall. Huntington, USA. hal 20-7.
22. Francischetti E.A, Genelhu V.A. 2007. Obesity-hypertension: an ongoing pandemic. International Journal of Clinical Practice, 61(2): 269-80.

23. Sukkur A. 2009. Hubungan hipertensi dengan lingkar pinggang. Skripsi Poltekes Surabaya. Diakses di http://ml.scribd.com/doc/80325 792/Hubungan-hipertensidengan-lingkar-pinggang

24. Supariasa IDN, Bachyar Bakri, Ibnu Fajar. 2002. Penilaian status gizi. EGC: Jakarta. 